\title{
War with Russia?
}

\section{Glenn Diesen}

Stephen F. Cohen, 2019. War With Russia? Hot Books, New York.

Professor Stephen Cohen's latest book War With Russia? explores the origins of the new Cold War with Russia, the lack of democratic debate by the political establishment and media, and a possible war with the world's largest nuclear power. Cohen's academic and diplomatic background makes him one of the few remaining Russian experts with extensive personal experience and knowledge about both the old and the new Cold War. As a long-time friend of Gorbachev and advisor to former President George H.W. Bush in late Cold
War years, Cohen was directly engaged in U.S.-Russian relations history. While initially working with Soviet dissidents, after the Cold War Cohen became a dissident of the U.S. because of his concern about Washington's aggressive policy against Russia based on a false and largely uncontested narrative. Cohen himself is a fascinating case study about what has gone wrong in American public discourse-armed with extensive academic and diplomatic experience from the Cold War, Cohen must nonetheless fight to have his voice heard in an environment hostile to dissent. Cohen's attempt to inform viewers about the other side of the

Glenn Diesen, PhD

Higher School of Economics, Moscow, Russia.

Professor

SPIN RSCI: 7360-7425

ORCID: 0000-0001-9343-6353

ResearcherID: T-1281-2018

Scopus AuthorID: 55303012200

E-mail: g.diesen@hse.ru

Address: Room 119, Malaya Ordynka 17, Bldg. 1, Moscow, Russia

DOI: 10.31278/1810-6374-2019-17-1-212-215 
argument, mainly Russia's perspectives, results in personal attacks rather than engaging with his arguments. The book lacks moderation, which the author himself recognizes in the introduction. Cohen starts the book with renouncing moderation of his words as he equates conformity to complicity. Instead, Cohen makes a remarkable contribution to the revival of public debate with this hard-hitting criticism of the political-media establishment that he argues have drifted far from common sense and responsible diplomacy. The unapologetic purpose of this book is to outline the counter-argument to an uncontested mainstream narrative.

Cohen's thesis is that the new Cold War is much more dangerous than the previous one that we barely survived. The peace movements calling for détente are missing, the rational concern for nuclear war is absent, civility towards Moscow's leadership is gone, democratic discourse and journalistic standards have diminished, and the buffer zone is lost as the faraway front line in Berlin has been moved to Russia's borders. Almost three decades after the Cold War was declared to be over, the credibility of political leaders in Washington is measured by the extent to which they are "tough on Russia." Diplomacy appears to be dead as getting along with Russia has become an accusation that was used to discredit political figures such as General Flynn and Tillerson. Trump's reasonable proposal that getting along with Russia would be "a good thing, not a bad thing" is tantamount to treason, and the public debate is non-existent as anyone not conforming to the neo-McCarthyist vilification of Russia are labelled useful idiots and Putin's apologists. Russia is crudely depicted as the reincarnation of the Soviet Union and Putin as the new Stalin-if not Hitler. Cohen describes a U.S. that has deluded itself to believing it is under attack by Russia and is eager to retaliate, while responsible voices calling for restraint have been shamed and silenced. Russiagate and the PutinTrump collusion still dominate the media after two years and have been accepted as a fact despite no evidence produced. A hot war is becoming increasingly possible as nuclear agreements are revoked and direct fronts established in both Ukraine and Syria.

How did we get here? Cohen deconstructs the narrative pushed by Washington's information war, which suggests the U.S. reached out to Russia in friendship in the 1990s on its path to democracy and membership in the European family of nations. The partnership was then supposedly disrupted by the rise of Putin's imperial 


\section{Review}

ambitions that destroyed Ukraine's dream of joining the Euro-Atlantic community. Cohen contests this narrative with facts that are rarely exposed to the American public due to the anti-Russian consensus of the political-media establishment. Cohen argues that relations between the West and Russia unravelled when NATO began its expansionism to the east, followed immediately by the invasion of Yugoslavia and forcible detachment of its historical province of Kosovo. The Western-backed color revolutions in Georgia and Ukraine in 2003 and 2004 were linked directly to NATO membership, which was then promised in 2008-followed by a war in Georgia. Cohen demonstrates that the narrative of the political-media establishment appears to be impervious to facts. Irrespective of the EU's independent report concluding that Georgia started the war in 2008, Russia is still blamed. Cohen argues that facts have also been distorted in the reporting and political discourse about the events that led to and followed the Western-backed coup in Ukraine in 2014. Similarly, after the West's disastrous and never-ending wars against Afghanistan, Iraq, Libya, and Syria-it is Russia that is blamed for "aggression against Syria."

Cohen argues that a partnership with Russia is imperative to address the key security challenges for the U.S., ranging from international terrorism to nuclear proliferation. Instead of addressing shared and important security challenges, Cohen worries that the new Cold War has made the U.S. ally itself with neo-Nazis in Ukraine and jihadists in Syria. Furthermore, anti-Russian policies are feared to derail Russia from its democratization process. The election of Trump, Cohen suggests, initially appeared to give way for improved relations. Trump's efforts to challenge the mistakes made since the 1990s to get along with Russia marked a break with a dangerous bi-partisan consensus for a new Cold War. However, concocting the Trump-Russia collusion story has intensified the new Cold War and made Washington more irresponsible as Russia has become a political tool in America's domestic politics. Despite no evidence of collusion, Cohen argues previous restraints have been abandoned as Russia stands accused of "attacking" the U.S., and anything short of a retaliation is appeasement. Akin to the red scare, the politicalmedia establishment also sees the allpowerful Putin behind every populist election and referendum across the West. As the U.S. approaches the 2020 presidential election, candidates with dissenting voices are certain to be 
denounced by the media as agents of the Kremlin.

A weakness of the book is Cohen's somewhat uncritical use of the term 'New Cold War.' The use of this term is paradoxical as it is also used by the political-media establishment to portray Russia as an expansionist empire in a zero-sum struggle to destroy America's freedoms. Concepts and historical analogies are helpful to convey a situation without spelling out the underlying assumption. However, invoking connotation about a familiar past also presents the risk of fighting the last war rather than adapt to new realities. Cohen's attempts to draw a distinction between the Soviet Union and Russia can be undermined with this historical analogy.

Cohen's arguments are controversial and debatable: Was Russia betrayed in the 1990s? Has NATO expansionism made the U.S. less safe? Did the U.S. topple the democratically elected Ukrainian government? Does Putin want a stable West? Does the U.S. need Russia to resolve its most pressing security challenges? Has U.S. belligerence pushed Russia into China's embrace? Has the media distorted and criminalized Putin and Russia? Did Russiagate demonstrate the corruption of U.S. intelligence services? Any of these arguments should create applause by Cohen's supporters and fierce opposition from his critics, which would be the starting point for a much-needed debate. This could indeed be the intention of the book. As we continue to drift towards war with Russia, there is a desperate need to present the other side of the argument. With this excellent book, Cohen makes a sound contribution to revive the public debate. 